\title{
Colorado Section Tours Unique Ranching Enterprise
}

\author{
By Ben Berlinger and Duke Phillips
}

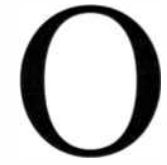

n May 14-15, 2004, the Colorado Section held its spring tour of the Chico Basin Ranch. The ranch was selected as the recipient of the Colorado Section's Excellence in Rangeland Management Award for 2003 (Fig. 1). This honor was presented to the ranch managers at the Section's annual meeting held in Fort Collins on December 4, 2003. As the citation for this prestigious award reads, the Chico Basin Ranch was nominated for 1) its innovative and holistic approach to land management and rangeland monitoring methods, 2) demonstrated land stewardship, and 3 ) outreach efforts to both fellow ranchers and the urban public.

The Section's tour was held jointly with the Colorado Chapter of the Soil and Water Conservation Society and was well attended with 65 participants (Fig. 2). The second day of activities involved the Section with the ranch's annual "Ecofest" workshop in which the public is invited to come to the ranch free of charge to learn about the ecology of the short-grass prairie ecosystem. Several of the ranch partners participated, such as the Rocky Mountain Bird Observatory, the Colorado Division of Wildlife, and The Nature Conservancy. This part of the tour offered the Colorado Section membership a unique opportunity to interact with the urban public regarding the role that rangeland science plays in the sustainable management of the short-grass prairie ecosystem.

The ranch is situated just east of Colorado's front range and is located 25 miles southeast of Colorado Springs. The Chico Basin Ranch is made up of a collection of ranches that were started in the 1870s. Most of these ranches were consolidated by the Drinkard and Emmert Company after the 1929 stock market crash. The Chico passed through several owners and one time included 175,000 acres.
More recently, the Chico was known as the Box T and today encompasses about 87,000 acres.

In the 1850 s, before ranching began in the Chico Basin area, parties of Cherokee Indians and white pioneers followed the Cherokee Trail from Bent's Fort in southeastern Colorado to Fort Bridger, Wyoming, where they struck the California Trail to the gold fields on the West Coast. The Chico Creek cutoff of the Cherokee Trail crossed part of what is now the Chico Basin Ranch (Whittemore 1990).

\section{Management Philosophy of the Chico Basin Ranch}

The Chico is managed as a private company, Box T Partners, and is operated by Duke Phillips and his wife Janet. Box $\mathrm{T}$ has leased the ranch from the Colorado State Land Board under a one-of-a-kind 25 -year-term agreement. Box T's management goals for the ranch provide for education and recreation along with a cattle ranching enterprise that supports long-term conservation, the persistence of biodiversity, and an economic basis for operations.

The people living on the Chico Basin Ranch make their livelihood by working in harmony with the living organisms and natural process of the ranch. Creating a quality of life and producing healthy food through economically and ecologically sustainable means is an important goal. They believe that all plant and animal life on the ranch is important and critical to the viability of the business, the ecosystem that supports it, and the lives of the people living on the ranch.

The managers of the ranch believe that a key to protecting the health of the land and food supply is building bridges between people in urban and rural areas so that they can reach an understanding that they both desire the same things: clean air and water, healthy food, and a healthy and sustainable 

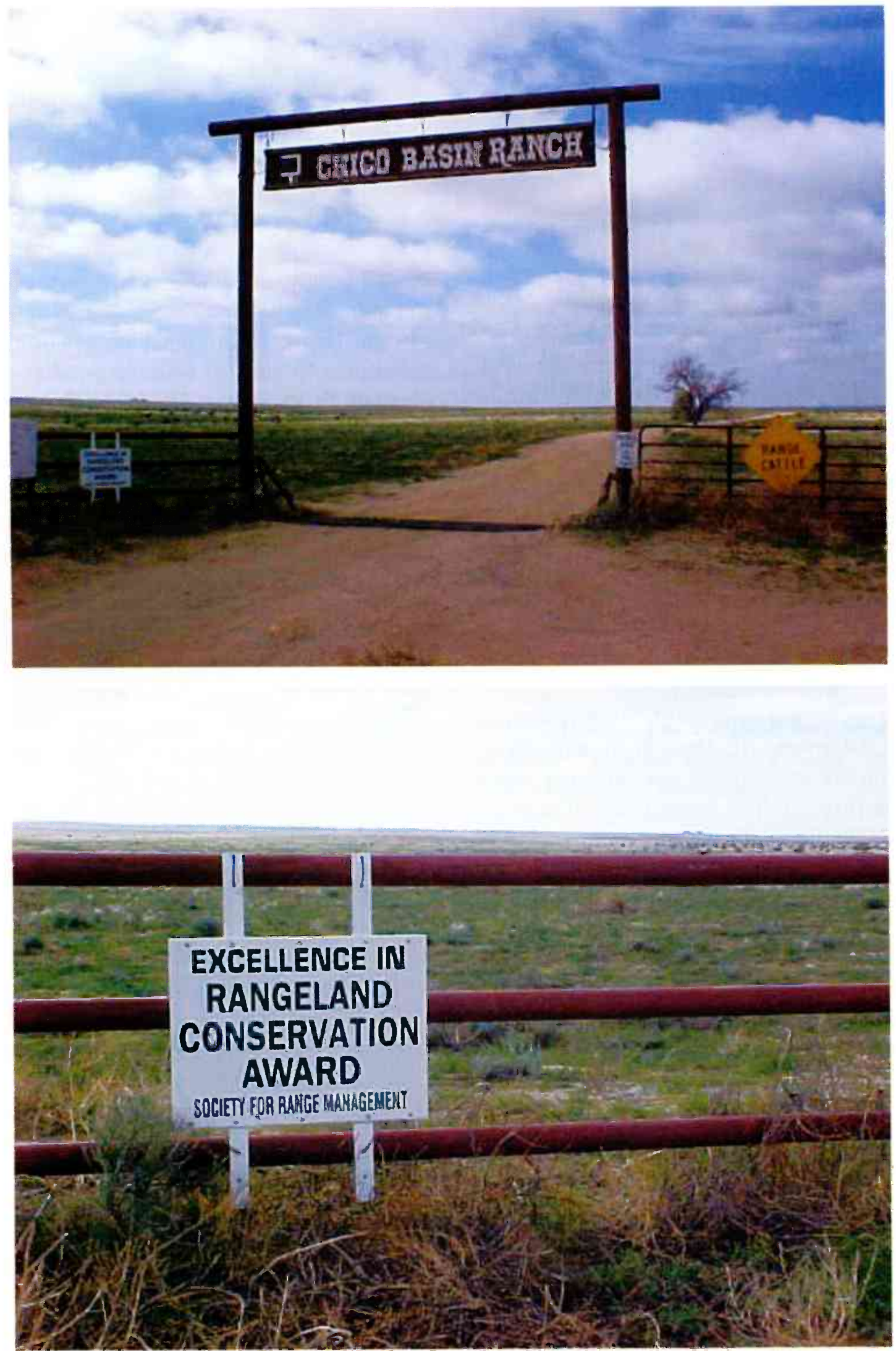

Figure 1. Gate at entrance to ranch. Colorado Section SRM award sign at entrance gate. 


\section{CHICO BASIN RANCH COLORADO}
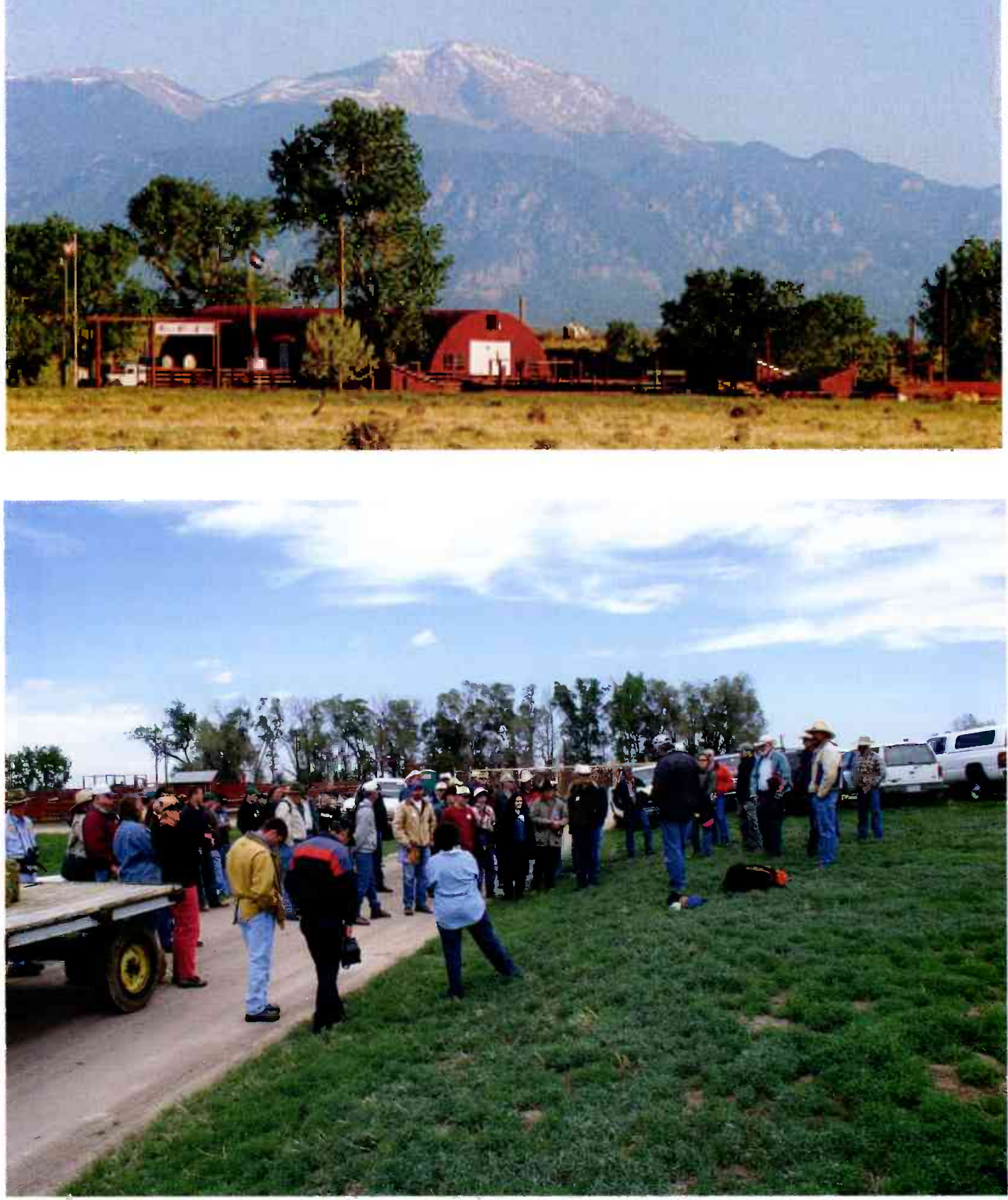

Figure 2. Web page logo [www.chicobasinranch.com] shows ranch headquarters. At ranch HDQ's before loading on hay waggons to start the tour. Participants are hearing from Wayne Leininger, Colorado Section SRM president. 

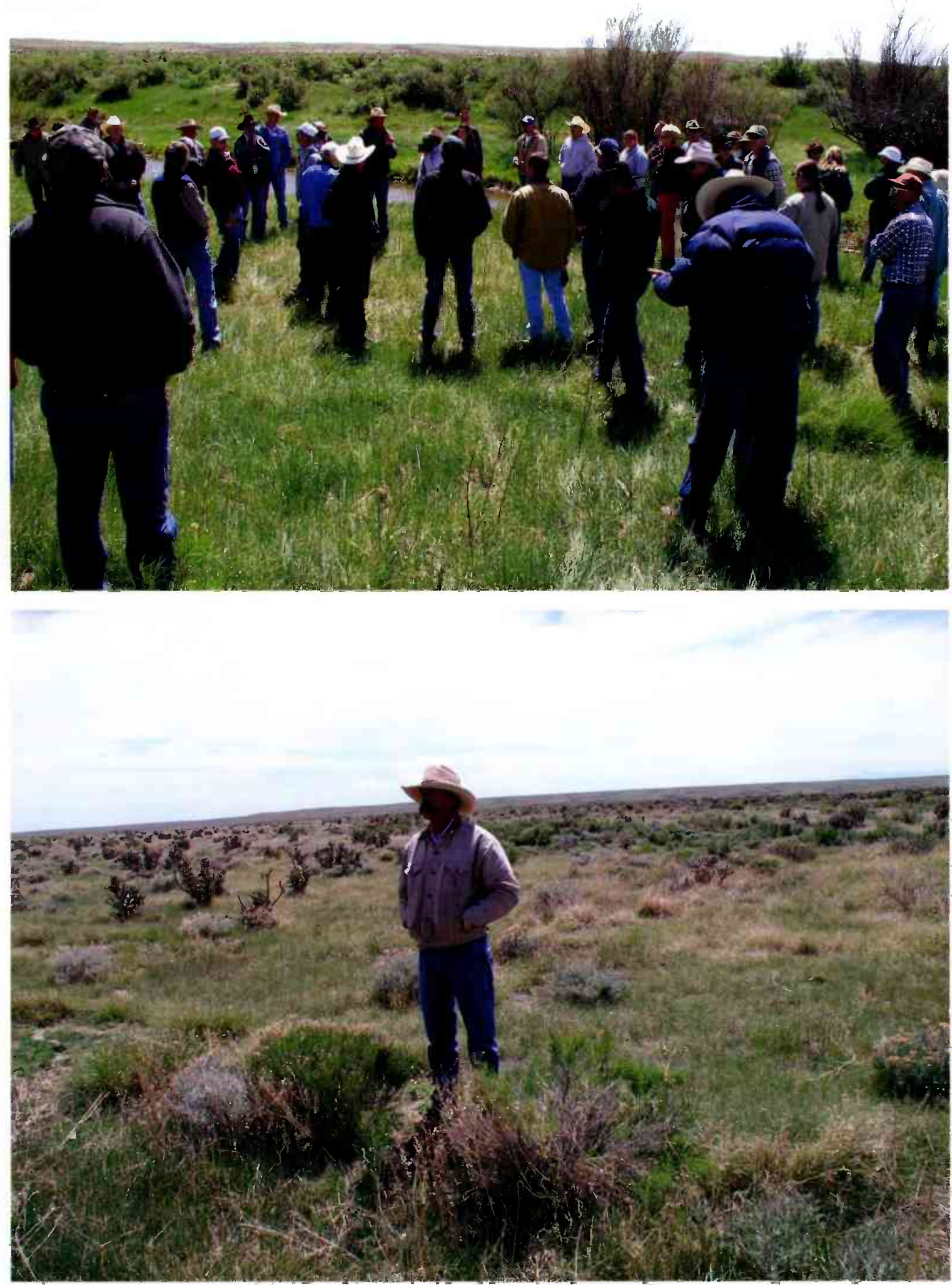

Figure 3. Tour stop made on the Chico Creek riparian area. Prescribed grazing management is advancing succession and improving riparian health. Duke Phillips discusses his grazing management in an upland pasture where a salt flat ecological site predominates. 
wildlife resource. Box $\mathrm{T}$ is involving people from rural and urban communities by providing opportunities for learning, recreation, and volunteering.

\section{Livestock Grazing}

The ranch grazes cow/calf pairs for the most part with yearling cattle used in some years. Livestock grazing is the main source of income for the ranch. Range livestock grazing has a rich history on the ranch. The Chico Basin is one of Colorado's largest historical cattle ranches. In the late 1800 s, Charles Goodnight grazed his cattle herds in this region of Colorado. A branch of the Santa Fe Trail also traversed through the ranch.

\section{Prescribed Grazing}

The tour gave an excellent firsthand look at the way grazing is managed on the Chico Basin Ranch. The goal in using grazing on the ranch is to maintain a healthy and diverse landscape coupled within a sustainable ranching enterprise. Cattle grazing is used holistically as a tool to manipulate the environment and improve that part or parts of the rangeland ecosystem that are the weakest link to a healthy system. Rangeland managers have 5 tools at their disposal: grazing, rest/recovery, animal impact, fire, and technology. All too often, technology has been used because the results are quickly seen. The Chico first applies the land management tools of grazing, animal impact, and rest/recovery and then evaluates the results.

The grazing prescription is determined at the start of the grazing season by Duke and his management team. The factors taken into consideration are current weather patterns, soil moisture conditions, rangeland conditions at the end of the last grazing season, and patterns of past grazing use. A grazing scheme is then developed for each of the main grazing areas on the ranch. Some basic grazing principles employed at all times are the following:

- Grazing will be rotated among the pastures available to each herd.

- Numbers of livestock will be determined to match as closely as possible the forage on offer in each grazing herd.

- The grazing and recovery periods in each pasture will vary each year to match the needs of the key plants.

- The date when grazing occurs will vary each year in all pastures.

Based on these axioms for prescribed grazing, the actual grazing scheme will be flexible and adaptive to the growing season conditions as they exist across the expanse of the ranch landscape. In the riparian and wetland areas, the pasture size is controlled as needed to achieve maximum effectiveness of each grazing event. This is accomplished using temporary electric fencing. The tour group was fortunate to see the main Chico Creek riparian paddock system, which is fenced on both sides and utilizes temporary electric fencing radiating off the side fences to achieve effective grazing paddocks of the desired size and shape (Fig. 3). Livestock water is provided through a developed system of pipelines and stock water troughs as well as predetermined locations along the Chico Creek.

\section{Rangelands of the Chico Basin}

\section{Rangeland Types}

The rangelands of the Chico Basin Ranch are quite diverse. The Colorado Section tour encompassed the central part of the ranch, which consists of alkaline plains and salt flat sites as well as several wetland and riparian areas. The Natural Resources Conservation Service (NRCS) recognizes 5 distinct ecological sites on the ranch. These include loamy, sandy, sands, alkaline plains, and salt flat sites. Riparian areas and wetlands are major lowland sites due to the ranch being traversed by 14 miles of Chico Creek, plus a handful of smaller streams.

The tour group stopped at a salt flat site and took an up-close and personal look at the plant community and ecosystem health (Fig. 3). In spite of the drought, the site looked impressive. The rangeland similarity index was determined to be in the high 60 s (referenced to the historic climax plant community), and the site's current productivity was estimated at 800 pounds per acre (air-dry). The dominant plants on the site are alkali sacaton, blue grama, western wheatgrass, and vine mesquite grass. Important species such as American vetch, fourwing saltbush, and winterfat are coming back. 
This is a very fragile and brittle site, and it was most impressive to all that this site was in such an improved condition in spite of the recent drought.

The annual precipitation in this area of the ranch averages 12 inches. Precipitation amounts on the ranch in 2002 were only about 3 inches, and 5 inches fell in 2003. Much-needed rain occurred in the spring of 2004, resulting in the start-up of good plant growth.

The other ecological sites visited on the tour were a loamy and a wet meadow site along the Chico Creek riparian system. The group discussion regarding the riparian areas led to the conclusion that current grazing management is advancing plant community succession and thereby improving biological diversity of these sites. Desirable shrub and tree species and several higher-successional grass, grasslike, and forb species are present and appear to be holding their place in the community.

\section{Monitoring Program}

The ranch uses the rangeland monitoring protocol developed by Charlie Orchard. The Land EKG methodology uses permanent line transects with intensive data gathering and photo points to make a reproducible record of the status of the plant community and associated ecosystem health. Monitoring is also used to determine rangeland trend. To date, the ranch has installed 12 of these monitoring sites. The health of the land and its systems is critical to both the business and the lifestyle on the Chico Basin Ranch. The ranch constantly monitors the land, water, and wildlife resources as measures of ecosystem health.

\section{Bob Budd's Keynote Presentation and Conclusion}

Bob Budd, SRM past president, gave the keynote address to the tour group at the luncheon/picnic on the last day of the tour. As only Bob can do so well, he left the group with a deeper appreciation for the connection between successful ranchers, sound grazing land management, and sustainable rangeland ecosystems in the world.

The tour by the Colorado Section was only one of several that will be conducted on the Chico Basin Ranch this year. To help the ranch management team with tracking and understanding complex ecosystem processes, the ranch has sponsored workshops in holistic management and ranch/grazing management schools. Professionals in ornithology, mammalogy, entomology, and botany regularly visit the ranch to help identify and monitor wildlife populations. The ranch is fortunate to enjoy working partnerships with such respected organizations as the Society for Range Management, Soil and Water Conservation Society, Rocky Mountain Bird Observatory, The Nature Conservancy, Colorado Natural Heritage Program, Colorado Native Plant Society, Colorado Division of Wildlife, Natural Resources Conservation Service, State Land Board, Colorado State University Cooperative Extension, Land EKG, and the Allan Savory Center for Holistic Management.

The Colorado Section's tour exemplified just how well this working relationship, together with the other partners, is resulting in excellence in rangeland management on the Chico Basin Ranch.

Authors are chairman, Colorado Section SRM ranch tour committee, La Junta, CO (Berlinger); and manager, Chico Basin Ranch, 22500 Peyton Highway South, Colorado Springs, CO 80928 (Phillips).

\section{Reference}

WHITTEMORE, L. 1990. An illustrated history of ranching in the Pikes Peak region. Colorado Springs, CO: Gowdy Printcraft Press. 